\title{
Cagar Budaya Sebagai Sumber Belajar Sejarah Lokal
}

\author{
Umi Hartati, Sumiyatun, Ardi Bangun Prasetyo \\ hartatiumi18@gmail.com \\ Universitas Muhammadiyah Metro
}

\begin{abstract}
Cultural Heritage is a heritage that needs to be preserved, but in reality there are still many people who do not have the awareness to maintain and maintain the potential of cultural heritage as the cultural heritage of the nation. The purpose of this research is to describe the potential cultural heritage of the Dutch colonial period and describe the inventory of dutch colonial relics can be used as a source of local history. This research approach is qualitative research. This research method uses descriptive research methods. This research was conducted in PTPN VII Sub-District of Bekri Central Lampung Regency. The data in the study was obtained through interview and observation methods. Data analysis techniques use descriptive analysis techniques. The result of this study is that the potential of cultural reserves is all power that can be developed from objects. The potential of cultural reserve in PTPN VII Sub-District of Bekri Central Lampung Regency is Bedeng panjeng, chimney, digester machine, manager's house, wells, art buildings, stage houses, bathrooms, public toilets, and afdeling conductors. The building is a potential cultural reserve in Bekri Sub-District of Central Lampung Regency, especially in the scope of PTPN VII. The potential of the cultural reserve can be used as a source of local history that is a relic during the Dutch colonial period
\end{abstract}

Keywords: potential of cultural heritage, a source of local historical studies.

\begin{abstract}
Abstrak
Cagar Budaya adalah warisan peninggalan sejarah yang perlu dilestarikan, akan tetapi pada kenyataannya masih banyak masyarakat yang belum memiliki kesadaran untuk menjaga dan merawat potensi cagar budaya sebagai warisan budaya bangsa. Tujuan penelitian ini adalah untuk mendeskripsikan potensi cagar budaya peninggalan masa penjajahan Belanda dan mendeskripsikan inventarisasi penginggalan masa penjajahan Belanda dapat dijadikan sumber sejarah lokal. Pendekatan penelitian ini adalah penelitian kualitatif. Metode penelitian ini menggunakan metode penelitian deskriptif. Penelitian ini dilakukan di PTPN VII Kecamatan Bekri Kabupaten Lampung Tengah. Data dalam penelitian diperoleh melalui metode wawancara dan observasi. Teknik analisis data menggunakan teknik analisis deskriptif. Hasil penelitian ini bahwa potensi cagar budaya merupakan segala daya yang dapat dikembangkan dari objek/benda. Potensi cagar budaya yang ada di PTPN VII Kecamatan Bekri Kabupaten Lampung Tengah yakni Bedeng panjeng, cerobong asap, mesin digester, rumah manajer,
\end{abstract}


Umi Hartati, Sumiyatun, Ardi Bangun Prasetyo

Cagar Budaya Sebagai Sumber Belajar Sejarah Lokal

sumur, gedung kesenian, rumah panggung, kamar mandi, toilet umum, dan kontor afdeling. Bangunan tersebut merupakan potensi cagar budaya yang ada di Kecamatan Bekri Kabupaten Lampung Tengah terutama di lingkup PTPN VII. Potensi cagar budaya tersebut dapat dijadikan sumber sejarah lokal yang merupakan peninggalan pada masa penjajahan Belanda.

Kata Kunci: Potensi, cagar budaya, sumber sejarah lokal

\begin{tabular}{lll}
\hline (C) $\underset{\text { EY }}{(\text { ) }}$ SA & This work is licensed under the Creative Commons Attribution-ShareAlike 4.0 \\
International License
\end{tabular}

\section{Pendahuluan}

Adanya Onder Afdeling pada masa penjajahan Belanda, meninggalkan banyak budayabudaya yang memperkaya khasanah kebudayaan di Kecamatan Bekri. Onder Afdelling di Kecamatan Bekri dipusatkan pada kegiatan perekonomian, yakni dengan membangun sebuah kantor dan perusahaan. Perusahaan yang ada di wilayah Bekri pada masa penjajahan Belanda tersebut berupa Perusahaan perkebunan kelapa sawit. Perusahaan ini menghasilkan minyak sawit yang dikirim kebeberapa daerah di Indonesia dan sebagian ke luar negeri. Adanya perusahaan milik Belanda, secara tidak langsung memberikan peluang kegiatan perekonomian di wilayah Bekri pada masa itu. Saat ini, perusahaan tersebut masih ada dan sebagian telah rusak dan sebagian lainnya telah di pugar. Kondisi masyarakat yang belum mengetahui tentang cagar budaya, belum mampu mengembangkan adanya potensi-potensi peninggalan masa penjajahan Belanda tersebut sebagai cagar budaya dan sebagai warisan budaya untuk dilestarikan sehingga dapat dijadikan pembelajaran sejarah.

Gambaran tentang bangunan-bangunan yang ada di kecamatan Bekri yang diduga mempunyai potensi sebagai bangunan cagar budaya, maka peneliti melakukan survei di kecamatan Bekri. Berdasarkan pra survey pada tanggal 2 Mei 2019 di Kawasan Bekri memiliki situs yang sangat menarik dan beragam potensi yang belum dikembangkan secara matang yaitu terdapat bangunan-bangunan bersejarah pada masa Belanda yang memiliki nilai sejarahsangat pentingdi Kawasan Bekri tersebut". "Potensi adalah suatu daya, kekuatan, kesanggupan dan kemampuan yang mempunyai kemungkinan untuk dapat dikembangkan."(Soleh 2017; Muhammad Syaifullah, Basuki Wibowo 2016). Hal ini tentunya sangat menarik apabila terbentuknya Cagar Budaya di Bekri ditarik mundur sejarahnya yaitu terdapat khasanah pengetahuan yang sangat unikdibanding daerah lain karena ciri khas wilayah Bekri terdapat di Perkebunan Sawit, dan bangunan-bangunan kuno masa Hindia Belanda. Ada beberapa faktor yang mempengaruhi usaha pemanfaatan alam sekitar sebagai sumber belajar yaitu: Kompetensi guru, Keberagaman peserta didik, dan Materi pembelajaran (Satrianawati, 2018). Dengan 
demikian bisa menjadi wawasansejarah untuk ilmu pengetahuan sebagai sumber belajar sejarah lokal untuk mengingatkan generasi saat ini bahwa di Daerah Bekri terdapat kearifan lokal sampai terbentuknya Bekri saat ini, serta tak lupa bahwa warisan budaya yang terdapat di Bekri harus dijaga secara sadar untuk kepentigan generasi saat ini dan masa yang akan datang. Pembelajaran sejarah sela-lu menjadi bagian dari komponen yang terkait secara padu untuk mencapai tujuan pendidikan nasional. Demikian pentingnya kedudukan ma-ta pelajaran sejarah yang menyebabkan mata pelajaran ini harus diajarkan seefektif dan seefisien mungkin untuk menumbuhkan jiwa patriotisme dan semangat nasionalisme (Astuti dan Suryadi, 2020).

Berdasarkan pra survei yang peneliti lakukan di Bekri generasi milenial kawasan Bekri sangat kurang kesadaran akan sejarah lokalnya khususnya mengenai peninggalan-peninggalan sejarah bangsa Belanda khususnya cagar budaya hal ini sangat memprihatinkan karenanya kurangnya rasa peduli terhadap sejarah lokal padahal generasi saat ini harus menjaga identitas bangsa agar kedaulatan NKRI terjaga. Peneliti juga menemukan berbagai bukti bangunan maupun peninggalan sejarah masa penjajahan Hindia Belanda yang lain sangat memprihatinkan kondisinya ada yang dialih fungsikan, ada juga yang dibiarkan begitu saja tanpa adanya perawatan maupun pelestarian. Seharusnya ada upaya pelestarian peninggalan sejarah di Bekri sebagai bentuk Cagar Budaya untuk mengapresiasi karena wilayah Bekri terdapat sejarahyang dimana untuk kontribusi penting bagi ilmu pengetahuan serta terdapat nilai-nilai nasionalisme yang terdapat wilayah tersebut.

"suatu bangunan layak untuk dipertahankan dan dijadikan bangunan cagar budaya apabila bangunan tersebut memiliki kriteria sebagai berikut: Estetika, yaitu dianggap mewakili gaya arsitektur tertentu; Kejamakan, yaitu bangunan yang tidak memiliki keistimewaan dalam gaya arsitektur tertentu namun dilestarikan sebagai wakil dari satu jenis bangunan; Kelangkaan, yaitu hanya ada satu dari bangunan sejenisnya atau merupakan contoh terakhir yang masih ada dari suatu jenis bangunan; Kesejarahan, yaitu memiliki nilai sejarah bangunan atau menjadi lokasi terjadinya suatu peristiwa bersejarah; Keistimewaan, yaitu memiliki kelebihan atau keunikan pada masa didirikannya, misalnya bangunan terbesar, tertinggi, ataupun terpanjang; Memperkuat kawasan di sekitarnya, lokasinya yang strategis sehingga investasi pada kelompok bangunan atau bangunan akan dapat meningkatkan nilai kawasan yang ada di sekitarnya." (Hidayat, 2014: 416-420; Volera Amanda Wirastari dan Rimadewi Suprihardjo; 2012)

Berdasarkan pendapat di atas dapat disimpulkan bahwa bangunan Cagar Budaya yang menjadi objek penelitian ini adalah Cagar Budaya berupa Bangunan yang ada di wilayah Bekri Kabupaten Lampung Tengah. Permasalahan selama ini adalah perhatian terhadap peninggalan sejarah sangat kurang. Melihat hal tersebut maka dukungan pihak perusahaan maupun pemerintah kabupaten Lampung Tengah khususnya harus berupaya mengoptimal diri dalam melindungi peninggalan-peninggalan bersejarah di wilayah kecamatan Bekri Kabupaten Lampung Tengah agar lestari dan optimal guna untuk pembelajaran sejarah masa kini maupun masa yang akan datang serta diharapkan masyarakat daerah Bekri khususnya harus mempunyai rasa saling memiliki agar saling menjaga, merawat, memanfaatkan dan tidak merusak 
Umi Hartati, Sumiyatun, Ardi Bangun Prasetyo

Cagar Budaya Sebagai Sumber Belajar Sejarah Lokal

peninggalan-peninggalan masa penjajahan Belanda di Bekri. Lingkungan dapat dijadikan sebagai laboratorium atau tempat bagi peserta didik untuk mendapatkan konsep dan informasi baru sebagai wujud dari hasil belajar peserta didik (Nurhajjah, Badarudin, dan Rahmawati, 2020).

Adanya inventarisasi yang akan peneliti lakukan berguna untuk melakukan pencatatan yang diduga terdapat peninggalan-peninggalan bersejarah baik berupa Benda Cagar Budaya, Bangunan Cagar Budaya, Struktur Cagar Budaya, Situs Cagar Budaya, dan Kawasan Cagar Budaya sebagai upaya untuk mendapat perlindungan sesuai UU No 11 Tahun 2010 tentang Cagar Budaya. Dalam konteks mengembangkan sejarah lokal, diperlukan pendidikan yang mampu menanamkan nilai-nilai multikultural dalam kehidupan peserta didik agar tercipta generasi muda yang mampu menciptakan keharmonisan dalam bermasyarakat (Hardiana, 2017). Tujuan penelitian untuk mendeskripsikan potensi Cagar Budaya Peninggalan Masa Penjajahan Belanda di Kecamatan Bekri Kabupaten Lampung Tengah dan Untuk mendeskripsikan Inventarisasi peninggalan sejarah masa Penjajahan Belanda dapat dijadkan sumber belajar sejarah lokal.

\section{Metode}

Penelitian ini dirancang dengan menggunakan penelitian kualitatif dengan jenis penelitian survei. Penelitian kualitatif adalah tradisi tertentu dalam ilmu pengetahuan sosial yang secara fundamental bergantung dari pengamatan pada manusia baik dalam kawasannya maupun dalam peristilahannya (Sugiyono, 2017; Bachtiar S. Bachri, 2010). Subjek data dalam penelitian adalah orang yang mengetahui segala potensi cagar budaya yang ada di Kecamat Bekri Lampung Tengah. Informan dimintai keterangan atau informasi terkait potensi cagar budaya. Informan yang dipilih yaitu Bapak Paino, Bapak Sukardi, Bapak Insan, Bapak Heriyanto dan Bapak Ig Sandiarta. Informan tersebut merupakan tokoh masyarakat dan karyawan yang bekerja di perusahaan PTPN VII Kecamatan Bekri. Lokasi penelitian yang dilakukan adalah di Kecamatan Bekri Lampung Tengah khususnya di lingkup PTPN VII Bekri yang merupakan perusahaan sawit. Kehadiran peneliti dimaksudkan untuk melakukan pengamatan serta mencatat untuk menunjang penelitian yang dimaksudkan dan tidak membuat seolah kegiatan penelitian berlangsung ditentukan baik narasumber maupun informan dari masing-masing pihak terkait.

Instrumen penelitian menggunakan lembar wawancara dan lembar observasi. Teknik pengumpulan data dalam penelitian menggunakan teknik wawancara, observasi, dan dokumentasi. Data yang diperoleh dari informan harus memiliki validitas atau kelayakan sehingga dalam penelitian ini data yang diperoleh dilakukan pengecekan keabsahan data melalui empat langkah yakni kredibilitas, transferabilitas, dependabilitas, dan konfirmabilitas. Teknik analisis data dalam penelitian menggunakan analisis deskriptif yang meliputi: reduksi data, penyajian data, dan pelaporan hasil. 


\section{Hasil dan Pembahasan}

Potensi merupakan suatu kemampuan atau abilitas yang dapat dikembangkan dari suatu subjek maupun objek tertentu. Potensi cagar budaya merupakan suatu daya atau kemampuan suatu benda yang dapat dianggap sebagai cagar budaya atau warisan budaya bangsa yang memiliki nilai penting dalam sejarah, ilmu pengetahuan dan kebudayaan sebagai tanda suatu peradaban pada zaman tertentu. Sebagai benda yang memiliki potensi cagar budaya tentunya memiliki karakteristik dan persyaratan sehingga benda atau objek dapat dikatakan sebagai cagar budaya. Adapun karakteristik benda yang dapat dijadikan cagar budaya adalah: pertama, benda berusia minimal 50 tahun. Benda atau bangunan dapat dikatakan cagar budaya memiliki usia sekurang-kurangnya 50 tahun. Peninggalan bangunan di Bekri berupa Bedeng Panjang, Sumur, Kantor Administrasi, Rumah Manajer, Mesin Digester, Toilet Umum, Cerobong Asap, Rumah Panggung dan Gedung Seni merupakan cagar budaya yang berusia lebih dari 50 tahun. Hal ini mengindikasikan bahwa bangunan dan benda tersebut memenuhi kriteria sebagai cagar budaya. Proses identifikasi dari usia bangunan tersebut berdasarkan keterangan-keterangan dan informasi dari narasumber. Sebagian besar narasumber atau informan kunci maupun informan pendukung telah menyatakan bahwa bangunan dan benda telah memiliki usia lebih dari 50 tahun, lebih tepatnya bangunan dan benda tersebut telah ada sejak didirikannya PTPN 7 Bekri itu sendiri yakni pada tahun 1916. Hal ini berarti bahwa bangunan dan benda tersebut diperkirakan berusia 104 tahun hingga sekarang. Dengan demikian dapat disimpulkan bahwa kriteria pertama pada bangunan dan benda berpotensi sebagai cagar budaya sudah terpenuhi.

Kedua, memiliki masa gaya paling singkat beruasia 50 tahun. Masa Gaya adalah ciri yang mewakili masa gaya tertentu yang berlangsung sekurang-kurangnya 50 tahun, antara lain tulisan, karangan, pemakaian bahasa, dan bentuk bangunan rumah. Kriteria bangunan yang dapat dipertahankan dan dijadikan sebagai cagar budaya jika memiliki nilai estetika yakni dianggap mewakili gaya arsitektur tertentu (Hidayat, 2014;, Ari Widyati Purwantiasning, 2020) . Kriteria ini berkenaan dengan ciri khas bangunan pada masa tertentu. Potensi cagar budaya peninggalan masa penjajahan Belanda berarti memiliki ciri khas bangunan yang digunakan adalah bergaya atau berarsitektur Belanda. Bangunan seperti Bedeng Panjang, Rumah Manajer, dan Kantor administrasi memiliki corak arsitektur bergaya Belanda dengan ciri khas atap berbentuk prisma. Bangunan yang ditemui yang berpotensi sebagai cagar budaya telah dibugar karena pada dasarnya masih memiliki fungsi hingga sekarang, dikhawatirkan jika tidak dibugar akan beresiko pada keselamatan dari orang yang tinggal di bangunan tersebut. Walaupun telah mengalami pembugaran, namun kriteria atau ciri khas arsitektur Belanda dari bangunan tersebut masih ada. Sedangkan pada benda yakni mesin digester tidak mengalami pembugaran atau masih kondisi asli, mesin ini sudah mengalami kerusakan dan tidak pernah digunakan lagi hingga sekarang.

Selanjutnya, meliliki arti khusus bagi sejarah, ciri khas dari benda atau bangunan yang memiliki potensi sebagai cagar budaya adalah memiliki arti khusus dalam pengetahuan, pendidikan, sosial, ekonomi, dan kebudayaan bangsa. Semua cagar budaya tersebut dapat digunakan untuk dijadikan sumber pembelajaran sejarah yang berbasis konstektual (Milah, 
Umi Hartati, Sumiyatun, Ardi Bangun Prasetyo

Cagar Budaya Sebagai Sumber Belajar Sejarah Lokal

Suswandari, dan Armiyati, 2019). Bangunan dan benda yang ditemui di PTPN 7 Kecamatan Bekri bernilai ekonomi dan budaya. Pada dasarnya sebagian besar bangunan peninggalan Belanda tersebut ditujukan untuk perekonomian yakni pada perusahaan sawit Kecamatan Bekri dan sebagai penghidupan pada masyarakat sekitar. Akan tetapi nilai sosial dan budaya melekat pada setiap kehidupan bermasyarakat. Kehadiran Bedeng Panjang sebagai tempat tinggal karyawan PTPN 7 pada masa tertentu mengindikasikan kehidupan sosial masyarakat yang terjalin diantara penghuni bedeng panjang. Adanya kehidupan bermasyarakat tersebut mencerminkan adanya kerukunan antar suku dan agama sehingga nilai kepribadian bangsa yang tercermin dalam Bhineka Tunggal Ika dapat terjalin.

Berdasarkan kajian tersebut bahwa penginventarisasian benda atau bangunan yang menjadi cagar budaya di lingkungan Kecamatan Bekri mengacu pada kriteria yang disebutkan dalam UU No 5 tahun 1992. Adapun hasil inventarsisasi Cagar Budaya yang dihasilkan adalah berupa rumah panjang, sumur, cerobong asap, mesin digester, rumah manajer, kantor administrasi, toilet umum, dan gedung kesenian. Usia dari bangunan-bangunan tersebut berkisar antara 70-100 tahun, sehingga objek atau bangunan tersebut merupakan cagar budaya. Inventarisasi merupakan suatu pengumpulan, pengoleksian, dan pengamatan terhadap suatu objek amatan. Inventarisasi potensi cagar budaya adalah suatu pengumpulan terhadap bendabenda yang berpotensi sebagai cagar budaya yang memiliki nilai-nilai penting dalam sejarah, memiliki nilai pengetahuan, dan memiliki nilai budaya. Kegiatan inventarisasi merupakan kegiatan turun kelapangan mengumpulkan data tentang objek yang dijadikan penelitian yang ada didaerah tersebut. Kegiatan inventarisasi ini meliputi kegiatan eksplorasi dan identifikasi (Yuniarti, 2011; Acep Saepul Milah, 2019). Inventarisasi potensi cagar budaya dalam penelitian ini dilakukan di Kecamatan Bekri kabupaten Lampung Tengah pada wilayah Perusahaan PTPN 7 yang merupakan warisan atau peninggalan pada masa penjajahan Belanda. Benda-benda yang merupakan peninggalan Belanda tersebut telah ada pada masa itu dan masih ada sampai sekarang. Benda atau objek tersebut kini masih digunakan oleh pihak perusahaan maupun masyarakat sekitar. Adapun objek-objek yang ditemukan adalah bedeng panjang, rumah manajer, sumur, toilet umum, kantor administrasi, mesin digester, gedung kesenian, dan cerobong asap. Objek tersebut merupakan objek atau benda yang merupakan peninggalan pada masa Belanda dan masih ada sampai sekarang.

Menurut penuturan bapak Ig bahwa rumah manajer yang ada dalam lingkup PTPN 7 merupakan rumah yang dibangun pada masa penjajahan Belanda sebagai tempat tinggal pengelola pabrik. Rumah manajer telah mengalami pemugaran atau pembaruan akan tetapi unsur-unsur peninggalan masa penjajahan Belanda masih melekat. Rumah manajer ini memiliki nilai kebudayaan yakni seni pada bangunan, sehingga dapat dikategorikan dalam cagar budaya, selain itu usia dari bangunan ini mencapai lebih dari 80 tahun yakni sejak perusahaan PTPN 7 berdiri. Selanjutnya, objek lain yang berhasil dikumpulkan adalah sumur dan bedeng panjang. Hasil wawancara dengan informan yakni bapak Paino, dan bapak Insan menyatakan bahwa sumur yang ada di lokasi perkebunan sawit PTPN 7 adalah sumur yang sudah ada sejak dahulu. Sumur itu digunakan untuk penyuplai air di bedeng-bedeng tempat tinggal. Selain itu, sumur tersebut juga pernah digunakan oleh masyarakat sekitar untuk mengambil air atau menjadi 
sumber mata air karena pada musim kemarau sumur-sumur yang ada di penduduk sekitar mengering. Bedeng panjang dalam kawasan Afdeling 3 juga merupakan objek yang berpotensi sebagai cagar budaya, hal ini karena bedeng panjang tersebut berusia lebih dari 70 tahun. Nilai penting yang dapat diambil dari bedeng panjang tersebut sehingga dapat dijadikan cagar budaya adalah terdapat banyak kepala keluarga yang tinggal di bedeng panjang pada masa itu, sehingga terdapat hubungan kekerabatan atau hubungan sosial yang terjadi, sehingga keanekaragaman suku bangsa yang terikat dengan semboyan bhineka tunggal ika dapat terwujud.

Adanya potensi cagar budaya yang ada di Kecamatan bekri tersebut, menambah kekayaan budaya bangsa dan ciri khas masa sejarah Indonesia sehingga perlu untuk diinventarisasikan sebagai bahan belajar atau sumber belajar bagi generasi muda. Tujuannya adalah bahwa generasi muda harus menghargai peninggalan-peninggalan maupun warisan budaya atau dapat mengenang nilai-nilai penting yang ada dalam suatu objek budaya bangsa sehingga dapat meningkatkan rasa cinta terhadap tanah air. Benda cagar budaya memiliki arti khusus bagi sejarah, ilmu pengetahuan, pendidikan, agama, dan kebudayaan, cagar budaya ini perlu diketahui oleh masyarakat mengenai keberadaannya (Haryani dan Triyono, 2017). Oleh sebab itu, inventarisasi cagar budaya ini diharapkan dapat menambah koleksi sumber belajar pada pembelajaran sejarah lokal.

Belajar merupakan suatu proses interaksi antara individu dengan lingkungan belajar termasuk guru, media belajar, dan sarana belajar yang memiliki sebuah tujuan tertentu. Belajar merupakan suatu kebutuhan bagi setiap manusia, karena dengan belajar seseorang dapat meningkatkan pengetahuan, keterampilan, dan sikap yang semua itu baik bagi dirinya maupun orang lain dalam kehidupan bermasyarakat. Sebagai bagian dari interaksi terhadap lingkungan, belajar tentunya membutuhkan suatu sumber belajar yang dapat digunakan untuk menunjang kegiatan belajar. Sumber belajar yang dapat digunakan oleh seseorang dalam kegiatan belajar sangatlah banyak dan beragam jenisnya. Sumber belajar yang dapat digunakan oleh peserta didik dalam proses pembelajaran dapat berasal dari guru, buku, video, museum, dan sebagainya. Pengembangan pembelajaran sejarah bermuatan lokal perlu pula mencermati arah materi sejarah yang bersifat Indonesiasentris. Dalam menghadapi tantangan pembelajaran sejarah yang demikian ini, peran pendidik sejarah benar-benar menentukan selain sebagai pelaksana kurikulum dan pengembang kurikulum sejarah, juga harus mampu melakukan pengkajian sejarah lokal di sekitar tempat tugasnya (Siska, 2015).

Inventarisasi ini dapat digunakan sebagai sumber belajar sejarah berupa koleksi buku pembelajaran sejarah lokal. Secara umum, peserta didik di lingkup sekolah Menengah Atas, mendapatkan pembelajaran sejarah melalui sumber belajar buku, video, dan informasi dari guru. Sumber sejarah dalam inventarisasi ini termasuk ke dalam pembelajaran sejarah untuk Sejarah Kebudayaan Indonesia dan Sejarah Nasional Indonesia. Inventarisasi potensi cagar budaya yang telah dilakukan di kecamatan Bekri Kabupaten Lampung Tengah dapat dijadikan sumber belajar sejarah lokal pada Pembelajaran Sejarah Indonesia khususnya terkait dengan masa penjajahan Belanda. Dalam pembelajaran sejarah menggunakan hasil Inventarisasi ini peserta didik akan 
Umi Hartati, Sumiyatun, Ardi Bangun Prasetyo

Cagar Budaya Sebagai Sumber Belajar Sejarah Lokal

belajar nilai-nilai positif yang terkandung dalam penjajahan Belanda di Indonesia yang relatif lama. Penjajahan Belanda meninggalkan warisan yang ternyata dapat dimanfaatkan oleh masyarakat Indonesia. Dengan demikian, diharapkan hasil inventarisasi ini dapat menambah khasanah ilmu pengetahuan peserta didik dalam mencintai cagar budaya Nasional dan dapat melestarikannya.

\section{Simpulan}

Berdasarkan hasil penelitian yang telah dilakukan di PTPN 7 Bekri mengenai potensi cagar budaya peninggalan masa penjajahan Belanda maka dapat disimpulkan bahwa potensi cagar budaya merupakan segala daya yang dapat dikembangkan dari objek/benda. Potensi cagar budaya merupakan segala kemungkinan benda atau objek (bangunan, alam) yang dapat dikatakan sebagai cagar budaya. Potensi cagar budaya yang ada di PTPN 7 Kecamatan Bekri Kabupaten Lampung Tengah yakni bedeng panjang, toilet umum, cerobong asap, mesin digester, rumah manajer, sumur, kantor administrasi, dan gedung kesenian. Bangunan tersebut merupakan potensi cagar budaya yang ada di kecamatan Bekri terutama di lingkup PTPN 7 Bekri. Potensi cagar budaya tersebut dapat dijadikan sebagai sumber belajar sejarah lokal yang merupakan peninggalan pada masa penjajahan. Hal tersebut mengandung nilai penting sejarah karena Indonesia dijajah Bangsa Belanda 350 Tahun. Benda-benda tersebut merupakan kenangan sejarah bangsa Indonesia dimana bangunan tersebut menjadi bagian penting dalam kehidupan masyarakat Bekri dan sekitarnya. Saran yang dapat diberikan kepada pengurus PTPN 7 dan masyarakat kecamatan Bekri adalah agar lebih memperhatikan kembali bangunan yang berpotensi sebagai cagar budaya serta dapat melestarikan warisan budaya bangsa sebagai cagar budaya dan sebagai sumber belajar sejarah lokal.

\section{Daftar Rujukan}

Astuti dan Suryadi. (2020). Pemanfaatan Museum Ranggawarsita sebagai Sumber Belajar Sejarah Bagi Siswa SMA Negeri Di Kota Semarang. Jurnal Profesi Keguruan, 6(1), 9-21.

Bachtiar S. Bachri. (2010). Meyakinkan Validitas Data Melalui Triagulasi Pada Penelitian Kualitatif. Jurnal Teknologi Pendidikan, 10(1).

Hardiana, Y. (2017). Pembelajaran Sejarah Indonesia Berbasis Peristiwa-Peristiwa Lokal. HISTORIA: Jurnal Pendidik dan Peneliti Sejarah, 1(1), 41-46.

Haryani dan Triyono. (2017). Augmented Reality (AR) sebagai Teknologi Interaktif dalam Pengenalan Benda Cagar Budaya kepada Masyarakat. Jurnal Simetris, 8(2), 807-812.

Hidayat, W., Ganie, T. H., \& Harefa, J. (2019). Kajian Bangunan Bersejarah Dinilai Dari Historis Dan Estetika Kota Medan Provinsi Sumatera Utara. Saintek ITM, 31(2).

http://lampung.bps.go.id. Data Penduduk Tahun 2018. Diakses pada Tanggal 24 Maret 2020. 
http://lampungprov.go.id. Letak Geografis Bekri Lampung Tengah. Diakses pada Tanggal 24 Maret 2020.

Milah, Suswandari, dan Armiyati. (2019). Pemahaman Guru Sejarah Terhadap Pemanfaatan Cagar Budaya Sebagai Sumber Sejarah di Kabupaten. Jurnal Bihari, 2(1), 47-62.

Muhammad Syaifullah, Basuki Wibowo. (2016). Pemanfaatan Benda Cagar Budaya Sebagai Potensi Pariwisata dan Ekonomi Kreatif Bagi Masyarakat Sekitar di Kota Pontianak Kalimantan Barat. Jurnal Sejarah dan Budaya, 10(2).

Nurhajjah, Badarudin, dan Rahmawati. (2020). Persepsi Guru Sejarah Terhadap Eksistensi Museum Negeri NTB sebagai Sumber Belajar dan Media Pembelajaran. Fajar Historia, 4(1), 14-23.

Purwantiasning, Ari Widyawati. dkk. (2020). Kata Kota Kata Kita. Arsitektur UMJ Press: Jakarta.

Satrianawati. 2018. Media dan Sumber Belajar. Yogyakarta : Deepublish.

Siska, Y. (2015). Analisis Kebutuhan Bahan Ajar Sejarah Lokal Lampung Untuk Sekolah Dasar. Mimbar Sekolah Dasar, 2(2), 199-211.

Soleh, Muhammad. (2010). Potensi Cagar Budaya di Daerah Nganjuk Jawa Tengah Sebagai Bagian Dari Sejarah. Jurnal Pendidikan Sejarah. Vol. 01. No. 01. Agustus 2010.

Sugiyono. (2017). Metode Penelitian Pendidikan (Pendekatan Kuantitatif, Kualitatif dan R\&D) Bandung : Alfabeta.

Undang-Undang Nomor 5 tahun 1992 Tentang Benda Cagar Budaya.

Undang-Undang Republik Indonesia Nomor 11 Tahun 2010 Tentang Cagar Budaya.

Volera Amanda Wirastari, Rimadewi Suprihardjo. (2012). Pelestarian Kawasan Cagar Budaya Berbasis Partisipasi Masyarakat Studi Kasus: Kawasan Cagar Budaya Bubutan Surabaya. Jurnal Teknik ITS, 1(1).

Yuniarti. 2011. Belajar dengan Inovasi Pembelajaran. Jakarta: Bumi Aksara. 